\title{
MENINGKATKAN HASIL BELAJAR PKN MENGGUNAKAN MODEL PEMBELAJARAN ROLE PLAYINGPADASISWA KELAS XSMA NEGERI 2 TEMPUNAK TAHUN PELAJARAN 2017/2018
}

\author{
Ahmad Shohari \\ SMAN 2 Tempunak Kabupaten Sintang \\ E-mail:shohari_ahmad@gmail.com
}

\begin{abstract}
Improving the quality of education can be seen from the learning process that takes place at school. For this reason, an appropriate learning model is needed so that it can improve learning outcomes. The title in this study is to improve Civics learning outcomes using Role Playing learning in class X students of SMAN 2 Tempunak 2017/2018 Academic Year. The problems in this study are: Can Civics Learning outcomes can be improved by applying the Role Playing learning model to Class X students of SMA Negeri 2 Tempunak 2017/2018 Academic Year? Whereas the aim is to improve the learning outcomes of PKn students in Class X of SMA Negeri 2 Tempunak Academic Year 2017/2018 through the application of Role Playing learning models. This research is a Classroom Action Research, the subjects are class X students of SMAN 2 Tempunak, amounting to 22 people. The factor observed was the teacher and student activities in learning. In this Classroom Action Research following the stages in CAR, namely: (1) Planning; (2) Implementation of actions; (3) Observas and Evaluations and (4) Reflections. The analysis used is a qualitative analysis in the form of a percentage and the average value of learning outcomes, which are presented in tabular form. Based on the results of the study, an increase in learning outcomes.the first cycle showed an increase from 67.50 to 73.30 (an increase of 5.80 points) and the second cycle was 80.00 (an increase of 6.70 points from the first cycle). Thus it can be concluded that the learning outcomes of Civics Education subject matter can be improved through the Role Playing learning model in class X students of SMAN Negeri 2 Tempunak 2017/2018 Academic Year.
\end{abstract}

Keywords: Learning Outcomes, Role Playing learning models 


\begin{abstract}
Abstrak
Peningkatan mutu pendidikan dapat dilihat dari proses pembelajaran yang berlangsung pada sekolah. Untuk itu diperlukan model pembelajaran yang tepat sehingga dapat meningkatkan hasil belajar. Judul dalam penelitian ini adalah meningkatkan hasil belajar PKn menggunakan pembelajaran Role Playing pada siswa kelas X SMAN 2 Tempunak Tahun Pelajaran 2017/2018. Permasalahan dalam penelitian ini adalah: Apakah hasil belajar PKn dapat ditingkatkan dengan menerapkan model pembelajaran Role Playing pada siswa Kelas X SMA Negeri 2 Tempunak Tahun Pelajaran 2017/2018?Sedangkan Tujuannnya adalah untuk meningkatkan hasil belajar PKn siswa Kelas X SMA Negeri 2 Tempunak Tahun Pelajaran 2017/2018 melalui penerapan model pembelajaran Role Playing. Penelitian ini merupakan Penelitian Tindakan Kelas, subyeknya adalah siswa kelas XSMAN 2 Tempunakyang berjumlah 22 orang.Faktor yang diamati adalah aktifitas guru dan siswa dalam pembelajaran. Dalam Penelitian Tindakan Kelas ini mengikuti tahapan dalam PTK yaitu: (1) Perencanaan; (2) Pelaksanaan tindakan; (3) Observas dan Evaluasi dan (4) Refleksi. Analisis yang digunakan adalah analisis kualitatif dalam bentuk persentase dan nilai rata-rata aktivitas hasil belajar, yang disajikan dalam bentuk tabel. Berdasarkan hasil penelitian, terjadi peningkatan hasil belajar. siklus I menunjukkan kenaikan dari 67,50 menjadi 73,30 (meningkat sebesar 5,80 poin) dan siklus II sebesar 80,00 (meningkat sebesar 6,70 poin dari siklus I). Dengan demikian dapatdisimpulkan bahwa hasil belajar mata pelajaran PKn dapatmeningkat melalui model pembelajaran Role Playingpada siswa kelasXSMANNegeri 2 Tempunak Tahun Pelajaran 2017/2018 .
\end{abstract}

Kata Kunci :Hasil Belajar, model pembelajaran Role Playing 


\section{A. Latar Belakang}

Pendidikan merupakan salah

satu bentuk kegiatan dalam kehidupan manusia, yangberasal dari hal-hal yang bersifat aktual menuju pada hal-hal yang ideal. Hal-hal yangbersifat ideal berhubungan dengan cita-cita yang secaralangsungatautidaklangsungber tujuanpadasosokyang diinginkan,ini semua berhubungan dengan tujuan pendidikan dan tujuan hidup.

Peningkatan mutu pendidikan dapat dilihat salah satunya dari proses pembelajaran yang berlangsung pada sekolah tersebut, baik model pembelajaran maupun pendekatan yang digunakan. Proses pembelajaran di Kelas X SMAN 2 Tempunak belum sepenuhnya optimal. Ha lini tampak pada proses pembelajarannya yang masihc enderung monoton dan masih berpusat pada guru,banyak siswa yang ramai pada saat pembelajaran berlangsung. Siswa pasif dalam penerimaan informasi maupun dalam proses pembelajaran menganggap PKnsebagai ilmu yang penuh hafalan. Tingkat pemahaman siswa terhadap materi masih rendah.
Model pembelajaran maupun pendekatan yang digunakan guru kurang bervariasi sehingga siswa kurangdiarahkandanberinteraksiden ganobjekdanlingkungandunianyata siswa. Hal ini mengakibatkan rendahnya hasil belajar siswa kelas XSMA Negeri 2 Tempunak, dengan rata-rata hasil belajar sebesar 56,78. Rata-rata tersebut masih berada di bawah standar KKM yang ditetapkan pihak sekolah sebesar 65,00 .

$$
\text { Melalui metode }
$$
pembelajaran Role Playing siswa dapat bertindak dan mengekspresikan perasaan dan pendapat tanpa kekhawatiran mendapat sangsi. Mereka dapat pula mengurangi dan mendiskusikan isuisu yang bersifat manusiawi dan pribadi tanpa ada kecemasan. Bermain peran memungkinkan para siswa mengidentikasikan situasisituasi dunia nyata dan dengan ideide orang lain. Identifikasi tersebut mungkin cara untuk mengubah perilaku dan sikap sebagaimana siswa menerima karakter orang lain. Dengan cara ini, anak dilengkapi dengan cara yang aman dan 
kontrol untuk meneliti dan mempertunjukkan masalah-masalah diantara kelompok atau individu.

Berdasarkan pada uraian latar belakang masalah diatas, maka peneliti tertarik untuk mengkaji lebih luas permasalahan pembelajaran yang terjadi di kelas,yaitu dengan melaksanakan penelitian yang berjudul "Meningkatkan Hasil belajar PKn dengan Menggunakan Model Pembelajaran Role Playing Pada Siswa Kelas XSMA Negeri 2 Tempunak“.

\section{B. Metode}

\section{Setting Penelitian}

Penelitian ini dilaksanakan di Kelas XSMA Negeri 2 Tempunakpada semester ganjil tahun ajaran 2017/2018.Waktu penelitian adalah bulan Juli sampai dengan bulan Nopember 2017.

\section{Pelaksanaan Tindakan}

Penelitian ini adalah penelitian tindakan kelas dan pada pelaksanaannya direncanakan akan diadakan sebanyak 2 (dua) siklus yang didasarkan pada silabus pengajaran guru PKNkelas XSMAN
2 Tempunak. Setiap siklus yang dalam penelitian ini terdiri dari tahapan kegiatan, yaitu: perencanaan; (2) pelaksanaan tindakan; (3) observasi dan evaluasi; dan (4) refleksi. Secara rinci setiap tahapan kegiatan dijelaskan berikut ini:

1.pembuatanrencana pembelajaran Kegiatan yang dilakukan pada tahap ini adalah:

> Membuat/menyusun RPP

$>$ membuat lembar absen

$>$ Membuat skenario pembelajaran.

Membuat lembar observasi.

Menyiapkan alat bantu pembelajaran.

> Membuat LKS/ alat evaluasi.

$>$ Menyiapkan jurnal untuk refleksi diri.

2. Pelaksanaan Tindakan Sebelum Penjelasan

Kegiatan yang akan dilaksanakan pada tahap ini adalah melaksanakan skenario pembelajaran, yaitu 2 (dua) kali pertemuan untuk tiap siklus.Adapun langkah-langkah pelaksanaan tindakan sebagai acuan penyusunan skenario 
pembelajaran adalah sebagai berikut:
a. Kegiatan pendahuluan
b. Kegiatan inti
c. Penutup

3. Observasi dan evaluasi

Observasi dilakukan pada saat pelaksanaan tindakan. Setelah observasi dilakukan, peneliti bersama dengan guru mengadakan evaluasi terhadap pelaksanaan tindakan.

4. Refleksi

$$
\text { Berdasarkan hasil }
$$

observasi dan evaluasi peneliti bersama guru observer mengadakan refleksi yaitu mendiskusikan kelemahankelemahan pada saat pelaksanaan tindakan. Kelemahan-kelemahan yang terjadi selanjutnya akan diperbaiki pada perencanaan tindakan pada siklus berikutnya.

\section{Teknik Pengumpulan Data}

Teknik pengumpulan data dalam penelitian ini berdasarkan sumber data penelitian adalah :

1. observasi yaitu pengamatan terhadap aktifitas guru dan siswa dalam pelaksanaan pembelajaran.
2. Tes hasil belajar adalah pengungkapan kemampuan hasil belajar siswa dengan cara melakukan penilaian terhadap hasil isian LKS siswa.

\section{Indikator Kinerja}

Indikator keberhasilan dalam penelitian ini ada 2 (dua) macam, yaitu indikator tentang keterlaksanaan kegiatan pembelajaran yang termuat dalam lembar observasi dan indikator pemahaman konsep PKN siswa dalam bentuk hasil belajar.

1. Kegiatan pembelajaran dikatakan terlaksana dengan baik apabila minimal $80 \% \quad$ kegiatan pembelajaran terlaksana dengan sempurna.

2. Siswa-siswa yang menjadi subyek dalam penelitian ini dikatakan memahami konsep PKN yang diajarkan apabila minimal $80 \%$ jumlah siswa telah memperoleh nilai 65,00sesuai ketentuan dari sekolah bersangkutan atau memenuhi standar KKM.

\section{Pembahasan Dan Hasil \\ 1. Pembahasan \\ a. Aktifitas belajar siswa}


Aktivitas belajar siswa kelas XSMAN 2 Tempunakpada pembelajaran $\mathrm{PKn}$ di pertemuan pertama siklus I masih rendah terhadap aspek yang diamati dengan rata-rata persentase keaktifan berkisar 36,36\% sampai dengan $54,55 \%$. Sedangkan aktivitas belajar pada pertemuan ke dua siklus I dengan rata-rata persentase keaktifan terhadap seluruh aktivitas belajar yang dicapai siswa berkisar $45,45 \%$ sampai dengan 59,09\%.

Aktivitas belajar yang dicapai pada pertemuan ke-I siklus II terhadap seluruh aspek yang diamati dengan besaran persentase keaktifan berkisar 63,64\% sampai dengan $77,27 \%$. Sedangkan aktivitas belajar yang dicapai siswa pada pertemuan ke dua siklus II dengan besaran persentase berkisar $68,18 \%$ sampai dengan $81,82 \%$.

Secara skematis perbandingan dan kenaikan ketuntasan aktivitas belajar siswa dapat digambarkan sebagai berikut:

Gambar. 1 Diagram ketuntasan aktivitas belajar siswa Siklus I dan II

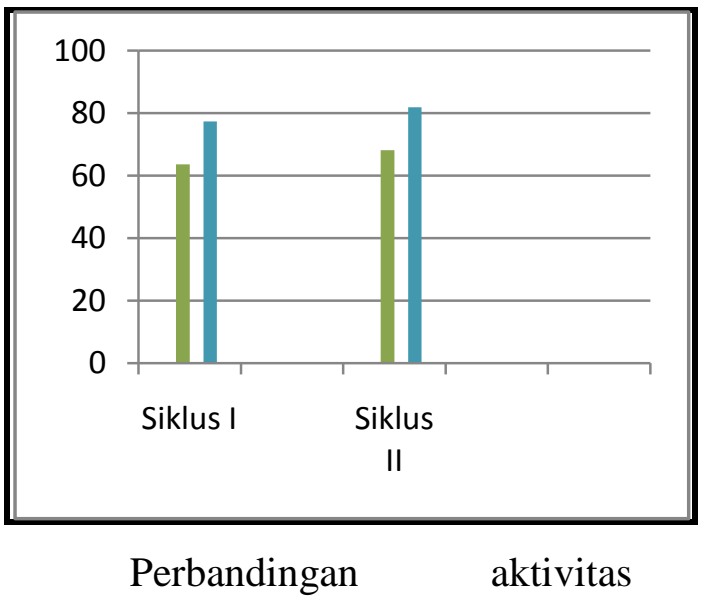

belajar siswa pada pertemuan pertama dan kedua siklus II menunjukkan bahwa ada perbedaan atau perubahan data angka frekuensi dengan data angka persentase keaktifan belajar, dimana data frekuensi dan data persentase pada pertemuan ke dua terlihat lebih tinggi terhadap seluruh aspek yang diamati. Dari tabel ditemukan bahwa telah terjadi peningkatan aktivitas belajar dengan besaran persentase peningkatan berkisar $4,54 \%$ sampai dengan 13,64\%. Berdasarkan hasil penelitian yang dikemukakan di atas bahwa aktivitas belajar siswa dalam kegiatan pembelajaran PKn yang dilakukan dengan menerapkan model pembelajaran role playing dapat meningkat.

\section{b. Hasil Belajar}


Secara skematis ketuntasan belajar siswa kelas XSMAN 2 Tempunakdapat digambarkan sebagai berikut.

Gambar. 2 Diagram ketuntasan hasil belajar siswa kelas XSMAN 2 Tempunak



Berdasarkan catatan lapangan bahwa aktivitas belajar PKN yang dilakukan oleh siswa dengan menggunakan model pembelajaran role playingternyata siswa sangat antusias. Hal ini terbukti bahwa dalam kegiatan pembelajaran aktivitas siswa terhadap seluruh aspek yang diamati dapat dilakukan oleh siswa, terutama pada sesi kegiatan mencari sumber/bahan belajar, mengkomunikasikan materi yang dibaca dalam kelompoknya, merekonstruksi atau menulis/mencatat sendiri jawaban dari masalah, mengajukan pertanyaan teman dan menghargai pendapat orang lain. Hal ini membuktikan bahwa model pembelajaran role playingdapat meningkatkan aktivitas belajar PKn pada materi Keberagaman suku bangsa.

\section{Hasil}

\section{a. Pelaksanaan tindakan siklus 1}

Pelaksanaan tindakan pada siklus I sudah dipersiapkan pada tahap perencanaan dan telah dibahas dengan guru mata pelajaran.kegiatan yang dilakukan pada pelaksanaan pembelajaran 01 dan 02 adalah melaksanakan skenario pembelajaran sebanyak 2 kali pertemuan. Setiap kali pertemuan dilaksanakan $2 \times 45$ menit (2 jam pelajaran). Pertemuan pertama dilaksanakan pada hari Senin tanggal 4 AgustusSeptember 2017 dihadiri oleh seluruh siswa kelas X dengan jumlah 22 orang.

Kegiatan pembelajaran diawali dengan guru memberi salam, memeriksa kehadiran siswa, dan menjelaskan model pembelajaran role playing. Setelah itu guru memberikan informasi kepada siswa berupa Lembar Kegiatan Siswa 
(LKS) yang memuat masalah. Setelah itu,ia membentuk kelompok kecil yang terdiri dari 4-5 siswa. Guru memberikan penjelasan tentang tugas yang akan dilaksanakan siswa dalam kelompoknya. Pembahasan masalah itu didikusikan menggunakan model pembelajaran role playing.Tahapan selanjutnya siswa menyimak, mengkritisi dan mencarikan solusi dari masalah yang diberikan guru.Mereka berinteraksi antar siswa dalam kelompok untuk membahas LKS.Selanjutnya masingmasing kelompok menunjuk perwakilannya untuk mempresentasekan hasil diskusi kelompoknya.Setelah presentase, maka terjadi diskusi antar kelompok.Setelah tahapan diskusi, maka guru dan siswa menyimpulkan materi.Selanjutnya masing-masing siswa membuat laporan hasil diskusi.Sebagai penutup guru memberikan evaluasi.

\section{Observasi}

$$
\begin{aligned}
& \text { Semua data yang berkaitan } \\
& \text { dengan proses dan produk } \\
& \text { pembelajaran diperoleh melalui } \\
& \text { observasi. Pengamatan proses adalah } \\
& \text { pengamatan yang dilakukan selama }
\end{aligned}
$$

siswa mengikuti pembelajaran, sedangkan produk adalah hasil tes yang dikerjakan oleh siswa setelah mengikuti kegiatan pembelajaran. Pengamatan dilakukan oleh guru PKn. Obyek pengamatan adalah aktivitas siswa selama pembelajaran dengan menggunakan lembar pengamatan.Kegiatan yang dilakukan dalam observasi adalah memperhatikan kegiatan yang dilakukan oleh guru dan siswa dalam pembelajaran.

\section{Pengamatan aktivitas siswa}

Berdasarkan hasil pengamatan peneliti, menunjukkan bahwa aktivitas belajar siswa pada pertemuan kedua ini pada aspek yang diamati telah menunjukkan adanya kemajuan.Hal ini terlihat bahwa pada setiap aspek yang diamati ada peningkatan.Pada aspek merekontruksi sendiri jawaban dari masalah hanya terdapat 14 orang siswa. Dalam pertemuan kedua ini ada 4 aspek yang sama dalam kegiatan pembelajaran yang dilakukan oleh siswa terhadap aspek yang diamati yaitu: mencari sumber/bahan belajar, mengkomunikasikan materi yang 
dibaca dalam kelompoknya, mengajukan pertanyaan pada teman dan memberi penjelasan pada teman terdiri 13 siswa. Secara keseluruhan aktivitas belajar siswa dalam kegiatan proses pembelajaran telah mengalami peningkatan.

Peneliti mencatat bahwa guru dalam memulai kegiatan pembelajaran selalu diawali dengan memberikan salam, selanjutnya memeriksa kehadiran siswa, memberikan motivasi, dan menggunakan model pembelajaran role playing. Selama proses pembelajaran berlangsung masih sering keluar di luar tanpa alasan, 1 (satu) orang siswa yang mengganggu temannya, dan 1 (satu) orang siswa yang mengkhayal. Kegiatan diskusi sudah mulai nampak, terbukti siswa yang diam pada pertemuan yang lalu sudah mulai berani mengeluarkan pendapat.

Berdasarkan tujuan dalam penelitian untuk meningkatkan aktivitas dan hasil belajar siswa, maka untuk mengetahui apakah telah terjadi peningkatan aktivitas belajar pada setiap pertemuan maka dapat dilihat pada tabel 1 .

Tabel 1: Perbandingan

\begin{tabular}{|c|c|c|c|c|c|}
\hline \multirow[t]{2}{*}{ No } & \multirow[t]{2}{*}{ Aktivitas yang diamati } & \multirow[t]{2}{*}{$\mathrm{N}$} & \multicolumn{2}{|c|}{$\begin{array}{l}\text { Jumlah siswa yang } \\
\text { aktif belajar }(\%)\end{array}$} & \multirow{2}{*}{$\begin{array}{l}\text { Skor Poin Peningkatan } \\
(\%)\end{array}$} \\
\hline & & & Tuntas & Tidak Tuntas & \\
\hline 1. & Mencari sumber/bahan belajar & 22 & $11(50,00)$ & $13(59,09)$ & 9,09 \\
\hline 2. & $\begin{array}{l}\text { Mengkomunikasikan materi yang } \\
\text { dibaca }\end{array}$ & 22 & $11(50,00)$ & $13(59,09)$ & 9,09 \\
\hline 3. & $\begin{array}{l}\text { Merenkontruksi atau } \\
\text { menulis/mencatat sendiri jawaban } \\
\text { dari masalah }\end{array}$ & 22 & $12(54,55)$ & $14(63,64)$ & 9,09 \\
\hline 4. & $\begin{array}{l}\text { Mempresentasekan hasil kerja } \\
\text { kelompok }\end{array}$ & 22 & $5(22,73)$ & $5(22,73)$ & p \\
\hline 5. & $\begin{array}{l}\text { Mengajukan pertanyaan pada } \\
\text { teman }\end{array}$ & 22 & $12(54,55)$ & $13(59,09)$ & 4,54 \\
\hline 6. & Menjawab pertanyaan teman & 22 & $p(40,91)$ & $10(45,45)$ & 4,54 \\
\hline 7. & Minta penjelasan dari teman & 22 & $13(59,09)$ & $12(54,55)$ & 4,54 \\
\hline 8. & $\begin{array}{l}\text { Memberikan penjelasan pada } \\
\text { teman }\end{array}$ & 22 & $\beta(36,36)$ & $10(45,45)$ & 9,09 \\
\hline 9. & Menghargai pendapat teman & 22 & $12(54,55)$ & $13(59,09)$ & 4,54 \\
\hline 10. & Membuat laporan & 22 & $\beta(36,36)$ & $10(45,45)$ & 9,09 \\
\hline
\end{tabular}

terdapat 1 (satu) siswa bercerita atau distribusi jumlah siswa yang belajar membicarakan hal-hal lain yang secara klasikal pertemuan ke-1,2 tidak ada hubungannya dengan (siklus I) pembelajaran, 1 (satu) orang yang 
Keterangan :

$\mathrm{N}=$ Jumlah Responden

$\mathrm{P} 1=$ Pertemuan ke-1

P2 = Pertemuan ke-2

Berdasarkan tabel 1 di atas diperoleh informasi bahwa kegiatan pembelajaran terhadap aspek yang diamati pada kegiatan proses pembelajaran dalam hal mencari sumber/bahan belajar dengan jumlah siswa yang aktif 11 orang atau 50\% pada pertemuan ke-1 dan mengalami peningkatan pada pertemuan ke-2 dengan jumlah siswa yang aktif 13 orang atau $59,09 \%$ dengan peningkatan sebesar 9,09 poin.

Kegiatan pembelajaran yang dilakukan oleh siswa dalam proses pembelajaran terhadap aspek yang diamati pada kegiatan pembelajaran dalam hal mengkomunikasikan materi yang dibaca yakni dari 22 orang siswa yang mengikuti kegiatan proses pembelajaran terdapat 11 orang atau 50\% siswa yang tergolong aktif pada pertemuan ke-1 dan meningkat pada pertemuan ke-2 dengan frekuensi 13 orang atau $59,09 \%$ siswa yang aktif dalam kegiatan pembelajaran dengan peningkatan sebesar 9,09 poin.
Kegiatan pembelajaran yang dilakukan oleh siswa dalam hal mengajukan pertanyaan pada teman yakni dari jumlah siswa sebanyak 22 orang yang mengikuti kegiatan proses pembelajaran yakni terdapat 12 orang siswa atau $54,55 \%$ yang tergolong aktif belajar pada pertemuan ke-1 dan meningkat pada pertemuan ke-2 dengan frekuensi 13 orang siswa atau 59,09\% siswa yang aktif dalam kegiatan pembelajaran dengan peningkatan sebesar 4,54 poin.

Kegiatan pembelajaran yang dilakukan oleh siswa dalam hal menjawab pertanyaan teman yakni dari jumlah siswa sebanyak 22 orang yang mengikuti kegiatan proses pembelajaran terdapat 9 orang siswa atau $40,91 \%$ yang tergolong aktif pada pertemuan ke-1 dan meningkat pada pertemuan ke-2 dengan frekuensi 10 orang siswa atau $45,45 \%$ siswa yang aktif dalam kegiatan pembelajaran dengan peningkatan sebesar 4,45 poin.

Aktivitas pembelajaran yang dilakukan oleh siswa dalam hal minta penjelasan dari teman yakni dari jumlah siswa sebanyak 22 orang 
yang mengikuti kegiatan proses pembelajaran terdapat 13 orang siswa atau $59,09 \%$ yang aktif pada pertemuan ke-1 dan menurun pada pertemuan ke-2 dengan frekuensi 12 orang siswa atau $54,55 \%$ yang aktif dalam pembelajaran dengan penurunan $-4,54$ poin.

Aktivitas pembelajaran yang dilakukan oleh siswa dalam proses pembelajaran terhadap aspek yang diamati pada kegiatan pembelajaran dalam hal membuat laporan yakni dari jumlah siswa sebanyak 22 orang yang mengikuti kegiatan proses pembelajaran terdapat 8 orang siswa atau $36,36 \%$ yang aktif pada pertemuan ke-1 dan meningkat pada pertemuan ke-2 dengan frekuensi 10 orang siswa atau $45,45 \%$ yang aktif dalam pembelajaran dengan peningkatan 9,09 poin.

Berdasarkan angka-angka dari tabel di atas dapat diperoleh informasi bahwa aktivitas belajar pada pertemuan pertama dalam proses pembelajaran masih rendah akan tetapi aktivitas belajar pada pertemuan ke dua dalam kegiatan pembelajaran telah terjadi peningkatan.

\section{Refleksi}

Berdasarkan kumpulan data yang diperoleh dari kolaborasi dengan guru PKn kelas $\mathrm{X}$ serta catatan lapangan yang ada pada peneliti, ternyata sebagaian besar siswa tingkat keaktifannya dalam pembelajaran masih rendah. Hal ini menunjukkan bahwa tujuan yang hendak dicapai sehubungan dengan pelaksanaan tindakan ini belum tercapai secara optimal.Menurut pengamatan peneliti kegagalan siswa tampak dengan jelas dalam membuat laporan hasil diskusi. Sebagian besar siswa belum mampu membuat laporan berdasarkan apa yang di diskusikan dengan kelompoknya dan kelompok lain.

Kegagalan siswa dalam mengerjakan tugas saat proses pembelajaran bersumber dari hal-hal berikut: 1). Siswa belum memahami tentang langkah-langkah kerja atau tahapan-tahapan pembelajaran yang harus dilalui pembelajaran menggunakan model pembelajaran role playing, 2). Masih ada siswa yang mengganggu teman pada saat diskusi berlangsung, 3). Guru belum memahami benar langkah-langkah 
pembelajaran menggunakan model pembelajaran role playing, 4). Kurangnya sumber atau bahan pembelajaran, 5). Guru masih kurang mengecek pemahaman siswa dan memberiikan umpan balik.

\section{Pelaksanaan tindakan siklus 2}

\section{Perencanaan tindakan}

Berdasarkan hasil identifikasi dan analisis kelemahan guru dan siswa pada pelaksanaan siklus I, maka peneliti bersama siswa kelas $\mathrm{X}$ dan guru PKn melakukan persiapanpersiapan. Secara kronologis persiapan pembelajaran siklus II dapat dilihat berikut ini.

- Membuat Rencana Pembelajaran (RPP)

- Membuat lembar observasi untuk memantau kegaitan siswa dan guru selama pembelajaran berlangsung.

- Menyiapkan perangkat pembelajaran yang diperlukan seperti buku paket, kertas folio untuk menulis laporan setiap kelompok.

- Menyiapkan materi yang akan dijadikan bahan pelajaran pada siklus II yaitu : Pengolahan dan Analisis data, dan penulisan
Laporan penelitian.

- Membuat tes evaluasi tindakan siklus II.

\section{Pelaksanaan tindakan}

Pelaksanaan pembelajaran dengan model pembelajaran role playing pada siklus II guru kembali berusaha melaksanakan pembelajaran sesuai dengan skenario pembelajaran yang telah ditetapkan. Waktu pelaksanaan tindakan siklus II ini berlangsung tanggal 15Agustus pertemuan pertama dan tanggal 18 Agustus2017 pertemuan kedua . Mekanisme pelaksanaan pembelajaran model pembelajaran role playing siklus II sama dengan mekanisme pelaksanaan pembelajaran model pembelajaran role playing pada siklus I yaitu sesuai skenario pembelajaran atau rencana pembelajaran nomor 05, dan 06 .

\section{Observasi}

Kegiatan observasi atau pengamatan pada siklus II dilakukan oleh peneliti bersama guru kelas $\mathrm{X}$ dan guru PKn pada dasarnya sama dengan pengamatan pada siklus I. Instrument yang digunakan sama dengan instrumen yang digunakan pada siklus I yakni: (1) Lembar 
obervasi, dan (2) Catatan Lapangan (observation note), dan (3) Tes Hasil belajar yang digunakan pada kegiatan evaluasi. Kegiatan yang dilakukan dalam obervasi adalah memperhatikan aktivitas yang dilakukan oleh guru dan siswa dalam pembelajaran.

\section{Pengamatan Aktivitas Guru}

Berdasarkan pengamatan nampak bahwa seluruh aspek $(100 \%)$ kegiatan pembelajaran yang dilakukan oleh guru pada pertemuan ke-1 dan ke-2 siklus II, telah dilaksanakan oleh guru.

\section{Pengamatan Aktivitas Siswa}

Aktivitas belajar siswa yang diamati dalam siklus II ini, sama dengan aktivitas yang diamati pada siklus I yaitu : 1) mencari sumber/bahan belajar (membaca), 2) mengkomunikasikan materi yang dibaca dalam kelompoknya, 3) merekontruksi atau menulis/mencatat sendiri jawaban dari masalah, 4) mempresentasekan hasil kerja kelompok, 5) mengajukan pertanyaan pada teman, 6) menjawab pertanyaan dari teman, 7) meminta penjelasan dari teman, 8) memberi penjelasan pada teman, 9) menghargai pendapat teman, dan 10) membuat laporan.

$$
\text { Hasil observasi yang }
$$
dilakukan oleh peneliti terhadap aktivitas belajar siswa pada pertemuan 1 siklus II secara kelompok menunjukkan bahwa aktivitas yang diamati sudah menunjukan keaktifan yang berarti. Hal ini dapat dilihat dari jumlah siswa dalam kelompok yang melakukan aktivitas belajar terhadap aspek yang diamati sebuah relatif tinggi bila dibandingkan dengan siklus I. pada aspek mencari sumber/bahan belajar (membaca), mengkomunikasikan materi yang dibaca dan merekontruksi atau menulis/mencatat sendiri jawaban dari masalah terdapat 17 orang siswa. Begitupula siswa yang mengajukan pertanyaan pada teman serta siswa yang menghargai teman juga terdiri 16 orang siswa. Secara keseluruhan aktivitas belajar siswa dalam kegiatan proses pembelajaran belum menunjukkan aktivitas yang diharapkan. Aktivitas siswa dalam kegiatan pembelajaran terhadap aspek mencari sumber/bahan belajar mengkomunikasikan materi yang 
dibaca dan merekontruksi atau menulis/mancatat sendiri jawaban dari masalah merupakan aktivitas yang paling tinggi yakni 17 orang siswa atau $77,27 \%$ dan terdapat 5 orang siswa atau $22,73 \%$ siswa yang tidak aktif belajar.

\section{Refleksi}

\section{Berdasarkan} hasil pengamatan yang dilakukan oleh peneliti terhadap aktivitas siswa kelas XSMAN 2 Tempunakyang diamati, dalam mengikuti proses pembelajaran di atas diperoleh informasi bahwa seluruh aktivitas belajar siswa telah terjadi peningkatan selama siklus II. Hal ini dapat diketahui berdasarkan kolom skor peningkatan yang terjadi, skor peningkatan yang terendah terjadi pada aktivitas belajar dalam hal mengajukan pertanyaan pada teman, memberi penjelasan pada teman dan menghargai pendapat teman dengan skor peningkatan sebesar 4,54 poin.

Sedangkan aktivitas belajar siswa yang diamati, terlihat pada kolom skor peningkatan yang tertinggi adalah terdapat pada aspek dalam hal memberikan penjelasan kepada teman dengan skor peningkatan sebesar 13,64 poin. berdasarkan penjelasan di atas dapat dikemukakan bahwa pelaksanaan kegiatan pembelajaran dalam penelitian tindakan kelas ini telah berhasil sesuai dengan rencana tindakan yang telah dipersiapkan oleh peneliti bersama dengan guru PKn.

Hasil pengamatan menunjukkan bahwa guru PKn dalam menerapkan model pembelajaran role playing telah mendapatkan ilmu baru, mendapatkan strategi baru dan mendapatkan kepuasan tersendiri, baik dalam proses pembelajaran maupun pasca pembelajaran. Tugas guru dalam upaya mendorong dan memotivasi para siswanya untuk mendapatkan prestasi menjadi lebih baik. Siswa mengalami peningkatan atau perubahan yang diharapkan antara lain: (a) peningkatan aktivitas belajar dalam pembelajaran PKn, terutama dalam merekonstruksi atau menulis/mencatat sendiri jawaban dari permasalahan (b) peningkatan pemahaman siswa terhadap hakikat pembelajaran $\mathrm{PKn}$, (c) berubahnya suasana pembelajaran dari suasana 
membosankan

menjadi

80,00 pada siklus II.

menyenangkan.

\section{Simpulan}

Berdasarkan hasil penelitian tindakan, maka dapat disimpulkan sebagai berikut:

1. Pembelajaran dengan menggunakan model pembelajaran role playingdapat meningkatkan aktivitas siswa kelas XSMAN 2 Tempunakdalam pembelajaran PKn yang ditunjukkan dengan meningkatnya partisipasi siswa dalam pembelajaran dalam setiap siklusnya. Hal ini ditunjukkan dari rata-rata aktivitas siswa pada siklus I adalah 61,58 sedangkan pada siklus II rata-rata aktivitas siswa meningkat menjadi 81 .

2. Penggunaan model pembelajaran role playingdapat meningkatkan hasil belajar PKNsiswa siswa kelas XSMAN 2 Tempunak. Hal ini ditunjukkan dari hasil rata-rata hasil test awal adalah 67,50, setelah menggunakan model pembelajaran role playing rataratanya menjadi 73,30 pada siklus I dan meningkat lagi menjadi

\section{Daftar Pustaka}

Aminah Siti, 2009, Penerapan Model pembelajaran Role Playing dalam Upaya Meningkatan Hasil Belajar siswa kelas $\mathrm{X}$ pada Mata Pelajaran Humas dan Keprotokolan di SMK Negeri 1 Kendari, SkrPKni Fakultas Keguruan dan Ilmu Pendidikan Universitas Haluoleo Kendari (tidak dipublikasikan).

Anang, Prasetyo. 2001. Metode Role Playing untuk Meningkatkan Hasil Belajar PKN kelas II SLTP N I Driyono Gresik. Buletin PelangiPendidikan. Edisi IV Tahun II.

Ansari, 2003, Meningkatkan hasil belajar matematika siswa kelas XSMA Negeri 17 Kendari mengggunakan model pembelajaran role playing,SkrPKni Fakultas Keguruan dan Ilmu Pendidikan Universitas Haluoleo Kendari (tidak dipublikasikan).

Arikunto, Suharsimi. 2006. Dasardasar Evaluasi Pendidikan. Jakarta: Bina Aksara.

Depdiknas. 2005. Penelitian Tindakan Kelas. Bahan Pelatihan Terintegrasi Berbasis Kompetensi Guru SMA di PPPG Matematika Yogyakarta. Dirjen Dikdasmen Direktorat 
Pendidikan

Lanjutan

Pertama.

Dimyati dan Mudjiono. 2002. Belajar dan Pembelajaran. Jakarta: Rineka Cipta.

Djamarah, S.B dan A.Zain. 2002. Strategi Belajar Mengajar. Jakarta: Rhineka Cipta

Hamalik, Oemar. 2001. Proses Belajar Mengajar. Bumi aksara. Bandung.

Mudhofir. $1986 . \quad$ Teknologi Instruksional. Bandung: Remadja Karya.

Mukminan. $\quad 1996 . \quad$ Strategi Penyampaian PKN. Departemen Pendidikan dan Kebudayaan: Jakarta.

Mulyasa, E, 2005,Menjadi Kepala Madrasah Profesional Dalam Mensukseskan MBS dan $K B K$. Bandung: PT. Remaja Rosda Karya

Mulyahardjo, 2004. Hakikat Pendidikan PKN. Jakarta: Departemen Pendidikan dan Kebudayaan.

Purwanto, Ngalim. 2004. Psikologi Pendidikan. Remaja Rosdakarya. Bandung.

Rahmat,Widodo.2009.http://wyw1d. wordpress.com/2009/11/09/m odel-pembelajaran-14-roleplaying/

Roestiyah. 1986. Didaktik Metodik. Bumi Aksara. Jakarta.
Rusyan, Tabrani. 1989. Pendekatan dalam Proses Belajar Mengajar. Remaja Rosdakarya Bandung.

Sanusi. 1997. Pendekatan bagi Anak Berkesulitan Belajar. Jakarta: Rhineka Cipta

Sudjana. 1992. Metoda Statistika. Tarsito. Bandung.

Suwarno, Wiji. 2006. Strategi Belajar Mengajar Biologi. Jakarta: Universitas Pendidikan Indonesia.

Usman, Muh. Uzer. 1993. Menjadi Guru Profesianal. Remaja Rosdakarya. Bandung. 